\title{
(2) \\ Watermelons in the Sand of Sahara: Cultivation and use of indigenous landraces in the Tombouctou Region of Mali
}

\author{
Brita Dahl Jensen, Fatoumata Maïga Touré, Mohamed Ag \\ Hamattal, Fatimata Aya Touré and Aminata Dolo Nantoumé
}

Photo Essay

\begin{abstract}
Watermelon (Citrullus lanatus (Thunb.) Matsum. \& Nakai) is mainly cultivated worldwide for its dessert type, sweet, red flesh fruits. Other types with white flesh are cultivated for their seeds more locally in some parts of the world. The cultivation and use of these watermelons are less documented than the dessert type watermelons. This photo essay describes and documents watermelon production and processing of seeds of indigenous, white flesh watermelons in the Tombouctou region of Mali. The crop is grown in sandy soils in the desert, relying on a short period of rain for the seed to germinate. In 2008 the watermelons were cultivated on around 540 ha in the region. Three watermelon seed types were identified: Fombou, Kaneye, and Musa Musa. For many people the seeds from these types are an important food source. In addition, dessert types called Kankani were also cultivated. The men take care of the field work related to the watermelon production and the women in the households process seeds into various snacks, flour to make sauces, and oil for meal preparations. Many use most of the seeds in their own household, and only surplus seed is sold on the market. Women, often organized in groups, are also engaged in local sale of the seed derived products.
\end{abstract}

\section{Abstract - French}

La pastèque (Citrullus lanatus (Thunb.) Matsum. \& Nakai) est cultivée dans le monde entier pour ses fruits à chair rouge et douce et est bien connue. D'autres types locaux de pastèque à chair blanche sont cultivés dans certaines parties du monde, principalement pour les graines. Ces types sont mal documentés. Ce 'photo essay' décrit et documente la production et la transformation des graines de pastèques locales dans la région de Tombouctou. La plante est cultivée sur des sols sableux dans le désert, avec une courte période de pluie permettant à la graine de germer. En 2008, ces pastèques ont été cultivées sur environ 540 ha dans la région. Trois types ont été identifiés: Fombou, Kaneye, et Musa Musa. Ces types constituent pour beaucoup de gens une source alimentaire importante. En plus, des types dessert étaient cultivés aussi, appelés Kankani. Les hommes s'occupent de la production et les femmes de la transformation des graines en croquettes, en farine pour faire la sauce, et en huile pour la préparation des repas. Beaucoup utilisent les graines de pastèques pour la consommation familiale, et seulement l'excédent est vendu sur le marché. Les femmes, organisées en groupes, sont également engagées dans la vente locale des produits de graines de pastèque au marché.

\section{Abstract - Bambara}


gne. Zere sukuya werew be ye an ka togo daw la munu konanan dje le do ani ulu be sene kisse de kama. Ulu

\section{Correspondence}

Brita Dahl Jensen, Department of Agricultural Sciences and Ecology, Faculty of Life Sciences, University of Copenhagen, Thorvaldsensvej 40, 1871 Frederiksberg C, DENMARK. dahl@life.ku.dk; brita_dj@hotmail.com

Mohamed Ag Hamattal and Fatimata Aya Touré, Mali-Folkecenter, Tombouctou, MALI.

Fatoumata Maïga Touré and Aminata Dolo Nantoumé, Laboratoire de Technologie Alimentaire and Programme Fruits et Légumes, Institut d'Economie Rurale, IER/CRRA-Sotuba, BP 262, MALI.

Ethnobotany Research \& Applications 9:151-162 (2011)

Published: April 15, 2011 


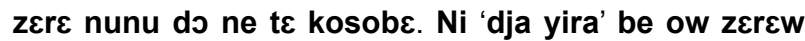
sine gnefo aw gne ani ka kissew bayeleme tjiogo fo


san dji fitini ba to kisse be fale. San 2008, tari 540

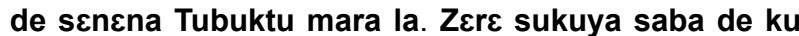
be: Fombou, Kaneye, Musa Musa. Jlu ye dumuni ye. Dowerew be munu dabo le do konola duni de ma. 0

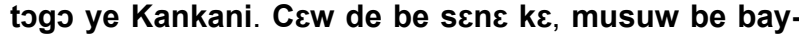

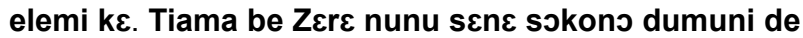
ma, a to doro de be fere suku la. Musuw, numu djere le do kulu ye, de be zere nunu kiss $\varepsilon$ dilan ani ka fere suku la.

\section{Introduction}

We usually think of watermelons (Citrullus lanatus (Thunb.) Matsum. \& Nakai) as juicy and sweet, red fleshed fruits to be enjoyed as a dessert or thirst quencher on hot days. In fact, it is a lot more than that. Watermelon types with more solid, white to cream and orange flesh are cultivated in some parts of the world. The flesh of these types is typically used as a vegetable for cooking, or the seeds are for instance used to prepare snacks, and flour is ground from the seed and used for sauces. The seeds are in this way a source of protein and fat in the diet (van der Vossen et al. 2004).

Watermelon is believed to originate from Africa, perhaps from the Kalahari Desert, or from a more northern part of Africa. Through many generations of domestication, plants adapted to certain areas have been nurtured by farmers, and farmers have more or less consciously selected preferred plants locally for specific purposes, for instance types that have good flesh or seed characteristics. This selection process has resulted in the development of so called 'landraces' (Zeven 1998).

In Mali, watermelons were grown on 15.000 ha in 2008 (FAOSTAT 2010). A major part of this production is sweet type watermelons for dessert. The production takes place in the western and central parts of the country (Kayes and Ségou regions), where the infrastructure allows for sale at local as well as more distant markets. Production of cooking, and in particular seed type white flesh watermelons, mainly takes place in the Gao and Tombouctou regions.

A legend suggests that a watermelon fruit plays a role for the foundation of Tombouctou town, the major town of the region with the same name. A girl named Bouctou was out herding the sheep. She fell, and the sheep went in front of her. She followed their tracks, when she suddenly was at a stream with a vigorous nearby forest, and her sheep were there too. The sheep liked to graze in the forest area, and as she was disoriented, she decided to stay there, living of the wild fruits and the milk from the sheep. After some months, her relatives went to look for her. On the way, her brother found a big fruit, which he had never seen before: It was a watermelon. He found his sister, they ate the fruit, - and a few days later the seeds germinated. Now, the sister did not want to leave her new place. She stayed, and her six brothers came to join her. They learned how to grow and make use of the watermelons. She was cooking a special thick porridge from watermelon seeds called Ikamayane. People passed and visited her, and finally Tombouctou was founded at the end of the eleventh century or the beginning of the twelfth century (Salem ould Elhadj 2008 pers. comm.). Local landraces of watermelon have most likely developed during centuries of selection by farmers in the region. Some of these landraces are rather distinct from what we usually consider watermelon, because the seed is the main reason for growing the crop.

During 2008, visits were made in regions of Mali to make a survey study related to the cultivation and use of indigenous watermelons. Observations and results obtained were documented by a series of photos. The present photo essay is based on photos from the Tombouctou region, taken in July and October 2008.

\section{Methods}

\section{The study area}

The study took place in the Tombouctou region, the most northern region of Mali. The region comprises the southwestern part of the Sahara desert. The town of Tombouctou is located at the southern fringe of the Sahara, near the Niger River, which is the main trade route to the capital Bamako and the Atlantic coast. The study included visits within a radius of $80 \mathrm{~km}$ from Tombouctou town in farmers' fields in the villages Intallassa (Commune Kondi/Diré), Kanaye (Commune Goundam) Ifazwane and Tidjéfen (Commune Alafia), Tinafewa (Commune Ber), Bellaferandi (Commune Tombouctou). Demonstrations of seed processing and food preparations were done by the womens' group 'ALBARAKA' in Bellaferandi at the outskirts of Tombouctou town.

\section{The camera and the photos}

Documentation of the watermelon habitat, cultivation practices, types, and transformation processes were made in the form of photos using a Nikon D80 digital camera with a Nikkor $18-135 \mathrm{~mm}$ lens. Photos were only taken after establishing a good report with the involved farmers and family members, and after explaining the purpose of the survey.

\section{Results}

\section{The watermelon habitat and importance of production}

The soils in the studied fields all contained more than $50 \%$ sand, and in the fields surrounding the Tombouctou 


\section{Jensen et al. - Watermelons in the Sand of Sahara: Cultivation and use of indigenous landraces in the Tombouctou Region of Mali}

town area, it was even $85 \%$. For the region, the minimum daily temperature (years 1950 to 2000 ) ranged from 13 to $27^{\circ} \mathrm{C}$, and the maximum daily temperature from 30 to $42^{\circ} \mathrm{C}$. The rainfall was during the same years in average $179 \mathrm{~mm}$ (World Weather 2010). With less than $250 \mathrm{~mm}$ precipitation per year, the region is characterized as desert. The major part of the rain falls in July and August. Due to the desert condition of the area, the main stable crops grown are millet and sorghum. Near the river it is possible to irrigate, and here rice, bean and vegetables are grown as cash crops.

The watermelons are produced by farmers who do not own land, and who have no access to land near the river with irrigation equipment. However, they have free access to cultivate the sand dunes more distant from the river. In



Figure 1. Watermelon land in the sand dunes in the region of Tombouctou, Mali. Sowing holes are prepared with a hoe. Seeds are sown in the holes and covered with sand. When the rain starts, the seeds germinate and seedlings emerge in the sand. Near the Niger river some farmers sow on islands arising when the river starts to draw back after the rain. Here, and on the shores of the river, farmers irrigate with water carried from the river in buckets. Otherwise, the crop relies only on the rain. (Photos from Intallassa and Tidjéfen, ( Brita Dahl Jensen). 


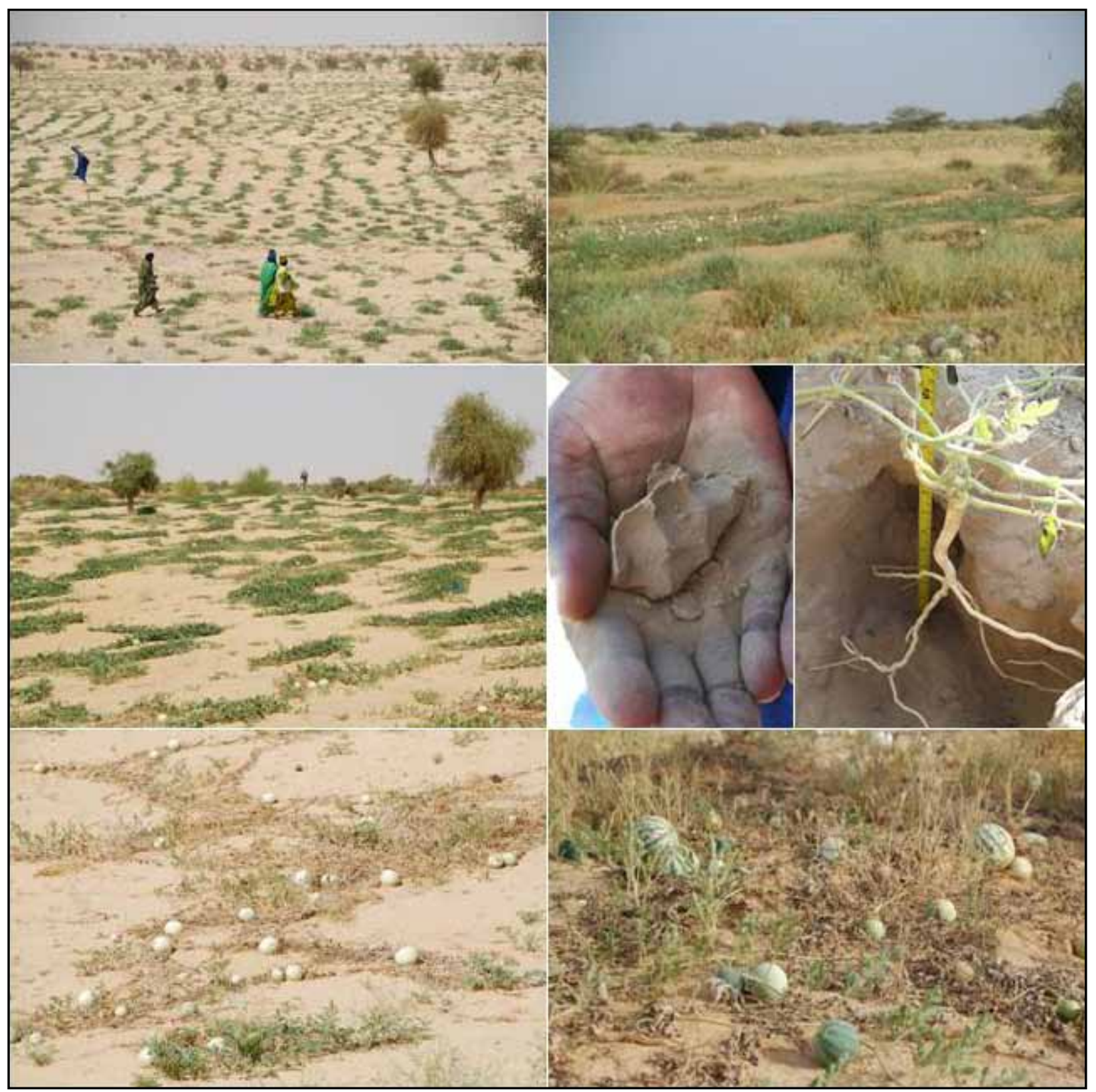

Figure 2. Watermelon fields in the region of Tombouctou, Mali. In some areas watermelon is the only crop which can grow in the sand. The fields cover large areas. The sand contains moist in the root zone, seemingly enough for the plants to survive. Wild or spontaneous plants of the type Birkinda are found in some fields. (Photos from Tinafewa, Bellaferandi and Tidjéfen, @ Brita Dahl Jensen).

some villages, this is the only crop that can grow under the prevailing dry and harsh conditions (Figures 1, 2). In some fields near the Niger River, where bucket irrigation is possible, watermelons are also grown, intercropped with other cucurbits and beans. The farmers are not organized in any way, and they receive less agricultural extension service than farmers growing cash crops near the river. The production area ranged typically from 1.0 to 4.0 ha per farmer but a few reported to have more than 10 ha.
According to the Ministry of Agriculture, Direction Nationale de Tombouctou, 540 ha of watermelons were grown in 2007-2008 and for the season 2008-2009 around 585 ha were sown. Between $85-100 \%$ of the area is believed to be planted with local genotypes (DRA 2008).

\section{The cultivation practices}

The crop is sown in the sand when the rain starts, usually in the middle of July (sec system). Farmers with produc- 


\section{Jensen et al. - Watermelons in the Sand of Sahara: Cultivation and use of indigenous landraces in the Tombouctou Region of Mali}

tion near the river (like Ifazwane/Tidjéfen) sow from July to August-September when the water level in the river after the rains starts to drop and makes it possible to sow on the shores and appearing islands (decrue system). The crop is rather heat tolerant and only relies on water to enable germination of the seed. The planting distance is approximately $1.5 \mathrm{~m} \times 1.5-2.0 \mathrm{~m}$. Two to five-six seeds are sown scattered in the sand in a hole prepared using a hoe. Once germinated, the watermelon plant itself is a robust runner, which soon covers a large surface. The production is carried out with no chemical fertilizers or pesticides, but some use a little manure to fertilise the crop. The fields were typically fenced by cut branches from acacia trees to avoid animal invasion, and the enclosures were generally made by the farmers in collaboration and contained several fields.

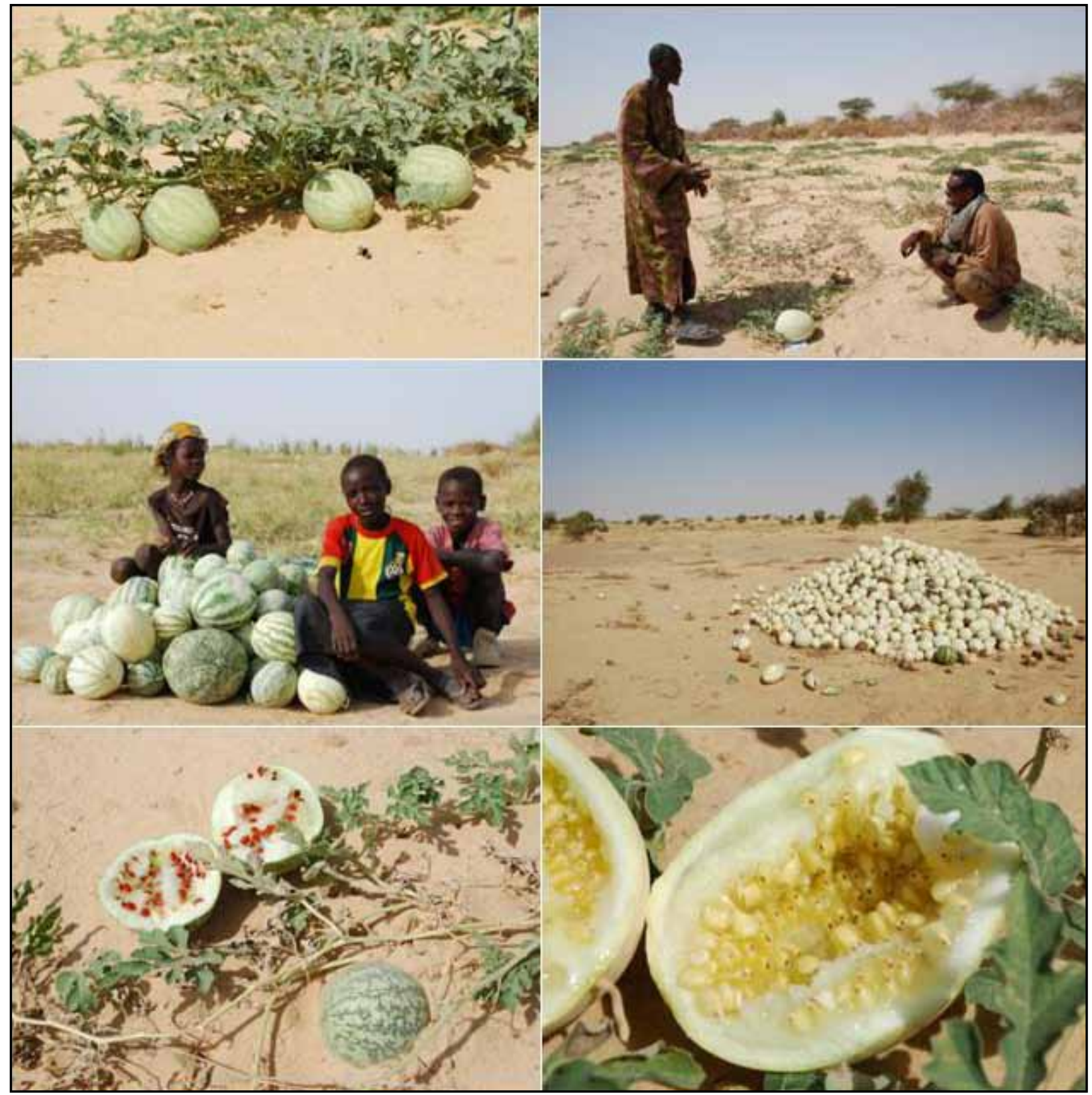

Figure 3. Watermelon fields ready for harvest in the region of Tombouctou, Mali. Fruits of the seed types are ready for harvest, and have been collected for harvest of the seed. Notice the variation of fruit shape and rind pattern. The flesh in the fruits is white. The type with the red seeds is Kankani Blanc, a sweet type only used for dessert. The type with the yellow seed is Musa Musa. The seeds are the main food source of this type. (Photos from Tinafewa and Kaneye, (c) Brita Dahl Jensen). 
The fruits can be harvested from around 3 months after sowing, typically in October-November, but some also indicated harvest until January-February (Figure 3). There are two harvest seasons: Those who use the flesh of the fruits for cooking (only in some areas) harvest the fruits early (before maturity), whereas those who use the seeds leave the fruits to ripen before they are harvested (Figure 4).

\section{Genotypes/seed types}

Three major watermelon 'seed' types were identified on the basis of shape and color of seed (Fombou, Kaneye, and Musa Musa), as well as a spontaneous 'wild type' (Birkinda). These types all had white flesh (Table 1, Figure 5). Others types called Kankani Blanc and Kankani Rouge with white or red flesh, respectively, were also cul-

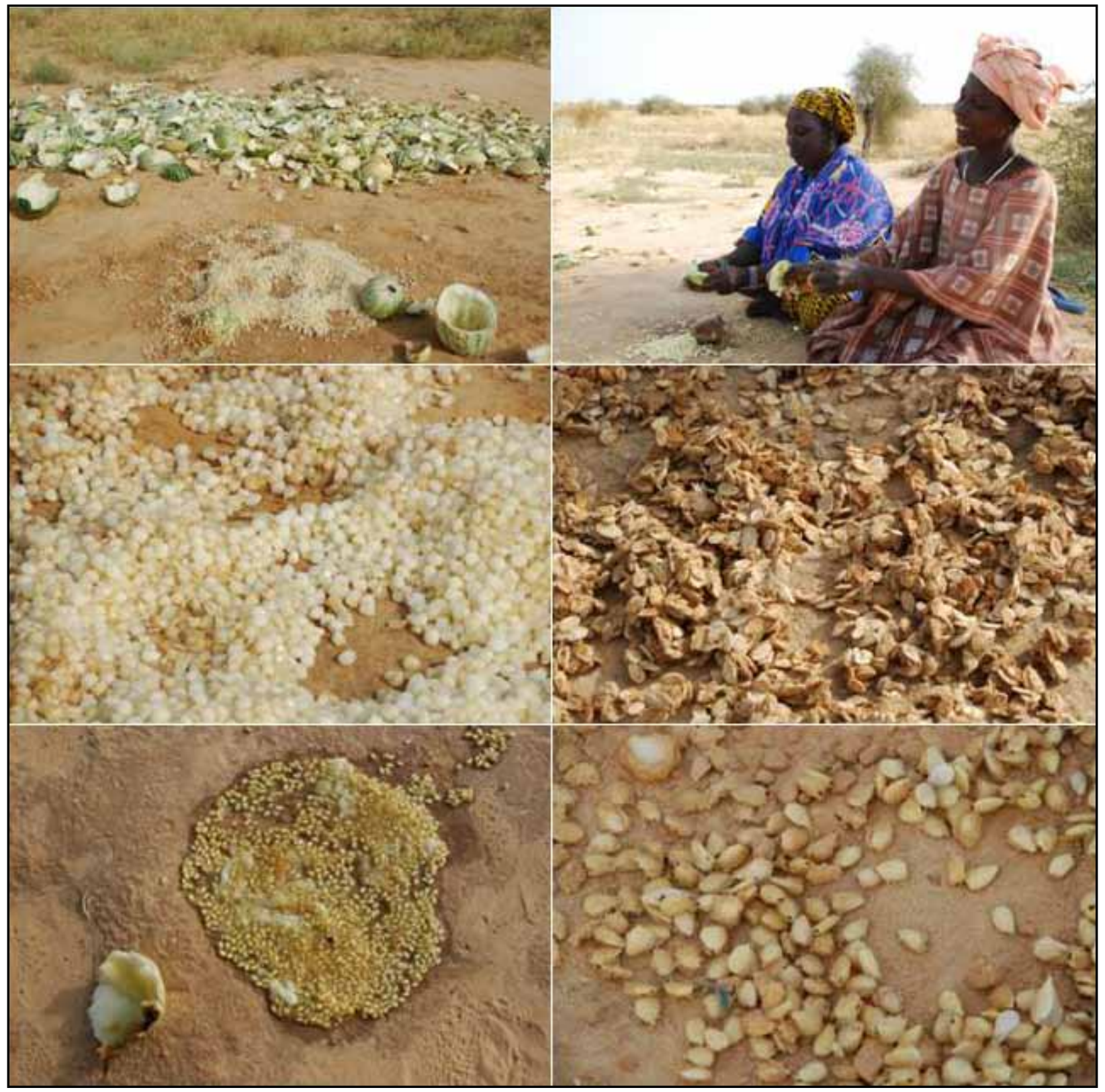

Figure 4. Watermelon seed extraction in the region of Tombouctou, Mali. The seeds are released when fruits are crushed on a stone. It is not until the seeds are out that that the seed type can be determined. Here, seeds of Kaneye are dried on the sand with the pericarp. This product is used to prepare a sauce. The seeds may also be fermented a couple of days in a shallow hole to loosen the pericarp before drying. These seeds are used to make flour. The remains of the fruit are fed to livestock. (Photos from Kaneye, (c) Brita Dahl Jensen). 


\section{Jensen et al. - Watermelons in the Sand of Sahara: Cultivation and use of indigenous landraces in the Tombouctou Region of Mali}

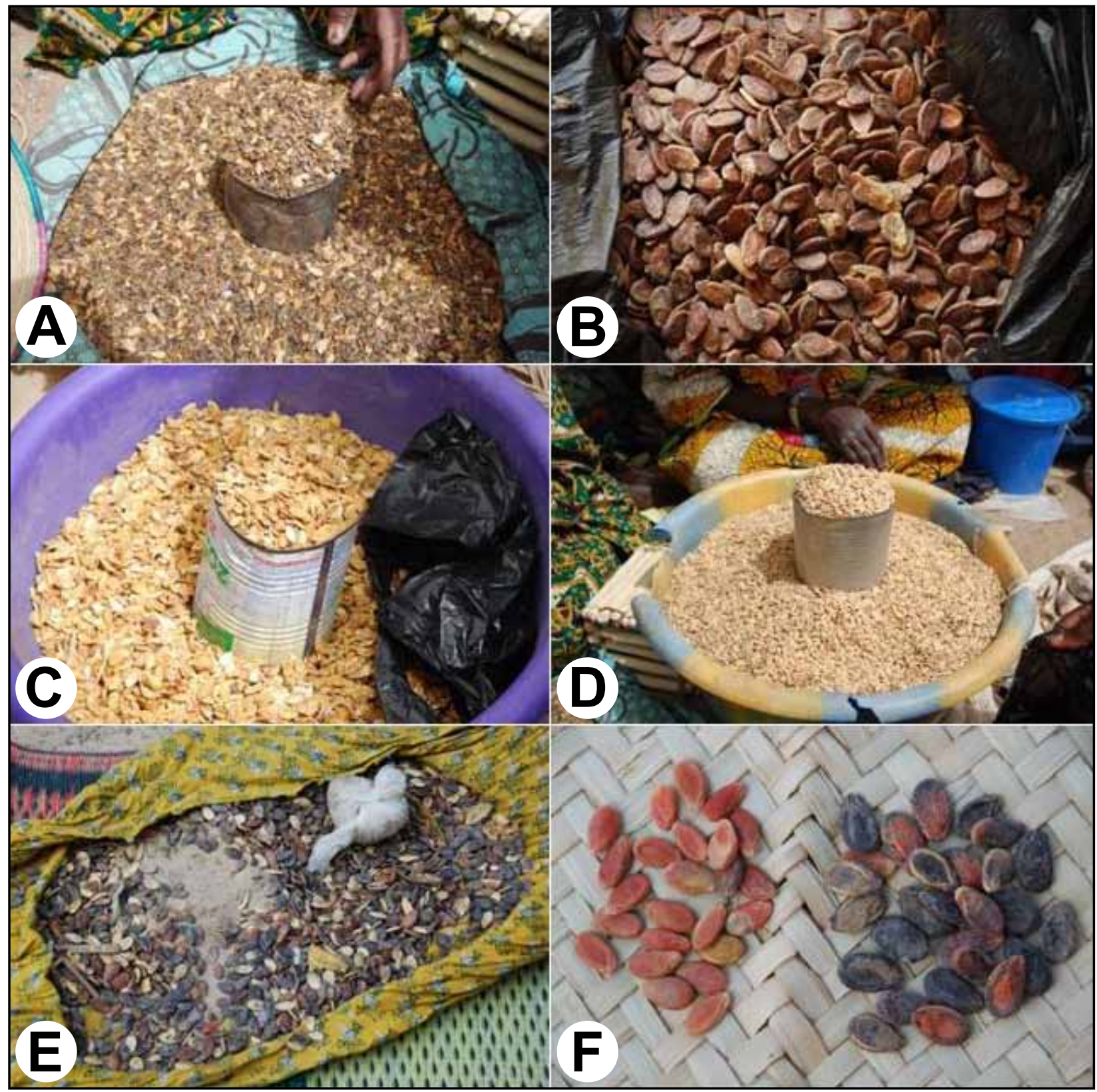

Figure 5. Watermelon types used in the region of Tombouctou, Mali. Seed of the different types are sold on the markets. A) Birkinda: A Wild or spontaneously grown seed type. Mainly used to feed chicken. On the markets it is often sold in a kind of mixture with other types. B) Fombou: A seed type mainly used to make a special snack called Bali Bali. C) Kaneye and D) Musa Musa: Yellow seeded types, mainly used for making flour, oil and special sauces, but also for snacks. $\mathbf{E}$ and F) Kankani Blanc: The flesh is sweet, and the fruit is used for dessert. (Photos from Tombouctou town, Diré and Alafia, (C) Brita Dahl Jensen).

tivated in the area, and the flesh was used for dessert. Diversity seems to exist among and within these types. In the field, fruit rind color and patterns may vary among and even within fields. When fruits are harvested, they are separated into fruit 'piles' with the expected different 'seed' types, but it is not until the seeds actually are harvested from the fruit that it is certain which type of seed it is. Seed harvest usually takes place in the field. The fruits are broken by hitting them on a stone, and the seeds are spread out to dry on the sand. Some types have seeds surrounded by a fleshy pericarp (Kaneye, Musa Musa). These seeds are left to ferment on the sand for a couple of days to loosen them from the flesh. Some Kanaye types are also dried and used with this pericarp. 
Table 1. Local watermelon types in the Tombouctou region of Mali, their known growing areas, seed and fruit characteristics. *Gao is a nearby region, and is considered a 'secondary center' of production, as watermelons most likely have been introduced to Gao from Tombouctou by boat on the Niger river.

\begin{tabular}{|c|c|c|c|}
\hline Type & Growing areas/where info obtained & Seed characteristics & Fruit flesh \\
\hline \multicolumn{4}{|l|}{ Seed use: } \\
\hline $\begin{array}{l}\text { Birkinda } \\
\text { (Wild/spontaneous) }\end{array}$ & Bellafarandi/Tombouctou, Kanaye & Dark brown/grey, small & $\begin{array}{l}\text { White,flesh, } \\
\text { small, firm }\end{array}$ \\
\hline Fombou & Bellafarandi/Tombouctou, Tinafewa, Gao* & Dark with red brown stripes, large & White flesh \\
\hline $\begin{array}{l}\text { Kaneye } \\
\text { (Bara-Bara/Ekanay) }\end{array}$ & $\begin{array}{l}\text { Bellafarandi/Tombouctou, Diré, Kanaye, } \\
\text { Tinafewa }\end{array}$ & Yellow, oval-round & White flesh \\
\hline Musa Musa & $\begin{array}{l}\text { Bellafarandi/Tombouctou, Diré, Goundam, } \\
\text { Kanaye, Tinafewa, Gao* }\end{array}$ & Yellow, slender, pointed & White flesh \\
\hline \multicolumn{4}{|l|}{ Fruit (dessert) use: } \\
\hline Kankani Blanc & Bellafarandi/Tombouctou, Tinafewa, Gao* & Dark brown & White flesh \\
\hline Kankani Rouge & Bellafarandi/Tombouctou & Dark brown & Red flesh \\
\hline
\end{tabular}

Often the different types are planted next to each other, or even, in some places, the seed of different types is mixed before sowing. Wild type watermelon fruit (Birkinda) is often seen in the fields. Farmers know that these fruits are problematic and that they will make the sweet type Kankani 'deteriorate' when they pollinate these, but they are not uprooted because they use them to feed their livestock.

\section{Uses and processing of watermelon seed}

Whereas the men are usually in charge of the production in the field, the women of the families are in charge of the use and transformation processes of the watermelons. Many women in Tombouctou town are organized in groups, for instance with an interest in the transformation of watermelon seed, and some even engage in local sale of their derived products. The seeds are a rich source of protein and oil (Loukou et al. 2007), and are made into various roasted snack products, flour and oil to be used in the daily food preparations (Table 2). During our visit the womens' group ALBARAKA demonstrated the preparation of: Bali Bali snack, Fombou Grillé snack, Musa Musa snack, Musa Musa flour, Musa Musa flour based sauce, and the sweet Hada snack based on Musa Musa (Figures 6-8). The group consisted of approximately 25 members and had a considerable sale of Bali-Bali, Fombou Grillé Salé (both snack products: casse-croute or amuse gueule) Musa Musa Grillé Salé, and Hada, a sweet snack based on the flour of Musa Musa with addition of sugar.

Table 2. Recipes of watermelon fruits and seeds in Tombouctou, Mali.

\begin{tabular}{|c|c|c|}
\hline Part used & Recipe & Product \\
\hline \multirow[t]{2}{*}{ Fruit } & Immature fruit flesh is eaten raw as a dessert. & Dessert \\
\hline & Immature fruit flesh is grilled or boiled. & \multirow[t]{4}{*}{ Snack } \\
\hline \multirow[t]{9}{*}{ Seeds } & Roasted and salted, or roasted and sugar added. & \\
\hline & Seed coat is removed and the kernels are roasted (Bali Bali). & \\
\hline & Flour is made of roasted seed, and sugar is added (Hada). & \\
\hline & Flour is used to cook porridge. Milk is added to the porridge (Bita). & Porridge \\
\hline & $\begin{array}{l}\text { Roasted or raw seeds are made into flour and added to make a sauce for rice or } \\
\text { couscous. }\end{array}$ & Sauce for food \\
\hline & $\begin{array}{l}\text { Flour of roasted seeds is made into balls with water and added to the sauce before } \\
\text { adding rice (Wichi). }\end{array}$ & \multirow[t]{2}{*}{ Rice dish } \\
\hline & Flour from seed is added to rice before completely cooked as a condiment. & \\
\hline & Flour from seed is boiled until the oil floats and this is recovered in a container & Oil \\
\hline & $\begin{array}{l}\text { Flour from seed is boiled until concentrated with a bit of potash. The concentrate is put } \\
\text { in moulds to shape before drying. }\end{array}$ & Soap \\
\hline
\end{tabular}



indigenous landraces in the Tombouctou Region of Mali

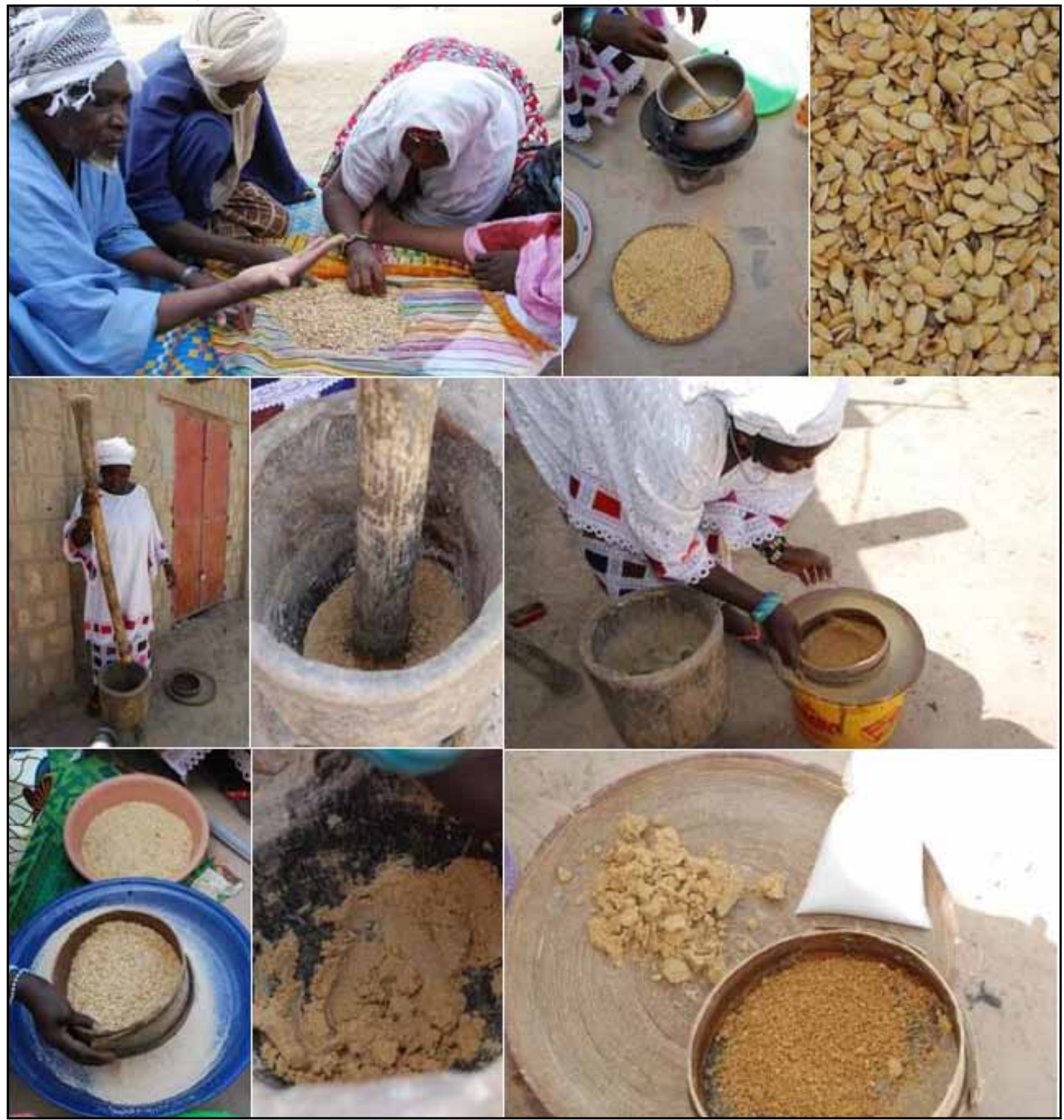

Figure 6. Seed processing into food items in the region of Tombouctou, Mali. Seed types are checked by villagers in Bellafarandi. Seed of Musa Musa and Kaneye is the basis for several preparations. Roasted seeds are prepared and consumed as a salty snack. The same process can be used for seed of Fombou. Seeds are also pounded into flour. The flour is separated by sieving. The process of pounding and sieving is repeated several times. After the final pounding an oily mass remains. Sugar or dates are added to make an energy rich, sweet snack called Hada. (Photos from Bellafarandi, (C) Brita Dahl Jensen).

\section{Conclusions}

This photo essay demonstrates the importance of watermelon as a crop and food source in the region of Tombouctou. It is our hope that the information obtained can be a first step: 1) to make strategies to conserve local genotypes; 2) to increase the production in a sustainable manner; 3) to improve quality of transformed products; and 4) to 'commercialize' the products to increase food security and income generation for families in the local communi- 


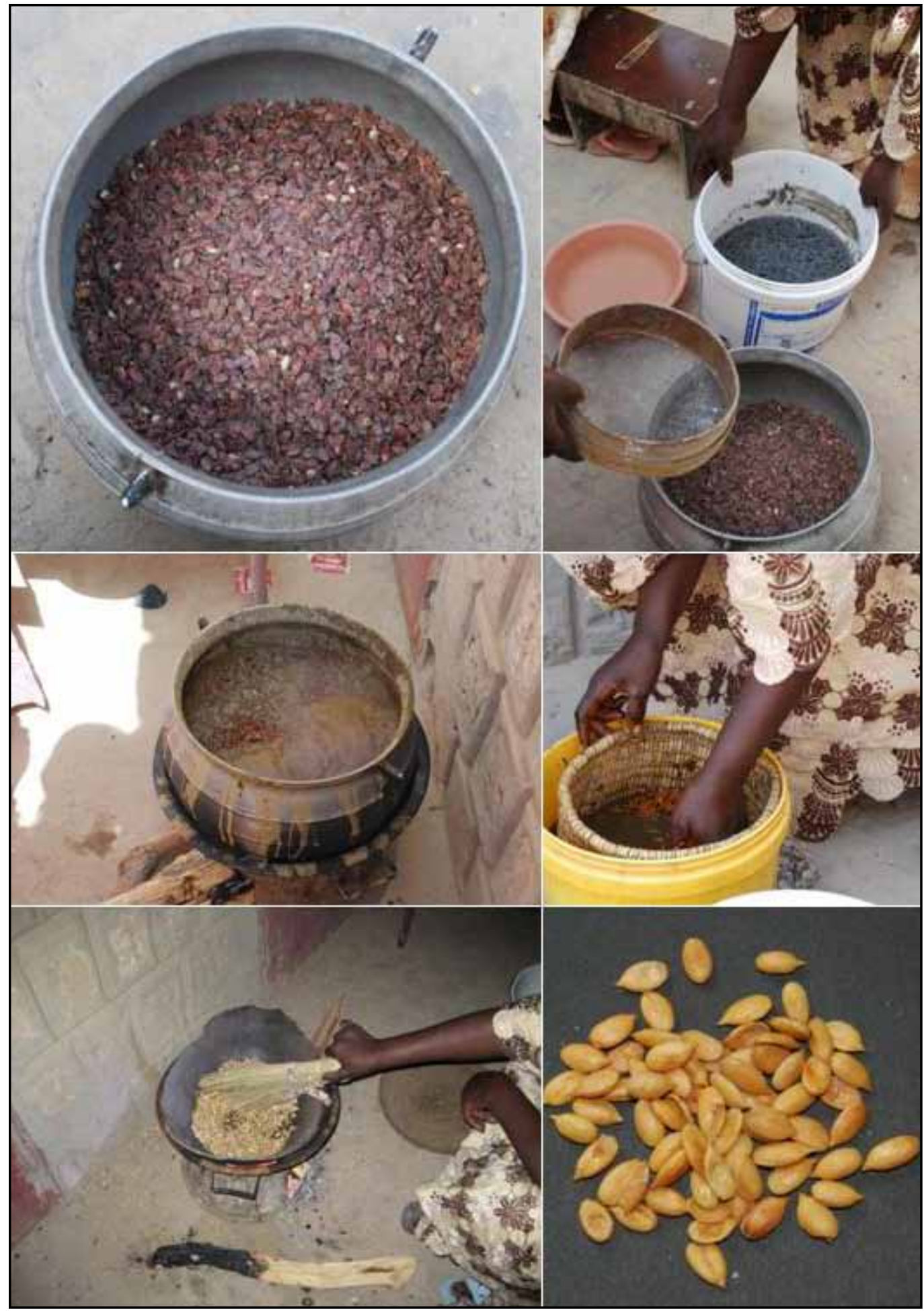

Figure 7. Seed processing into food items in the region of Tombouctou, Mali (continued). Seeds of Fombou are the basis for preparation of the snack Bali Bali. The preparation requires several steps. First the seeds are mixed with water and ash and boiled. Then the seeds are rinsed in water and left to dry in the sun. Finally, the seeds are put on the fire again so that the seed coat 'pop' open and can be separated from the final snack product Bali Bali. (Photos from Bellafarandi, () Brita Dahl Jensen). 


\section{Jensen et al. - Watermelons in the Sand of Sahara: Cultivation and use of indigenous landraces in the Tombouctou Region of Mali}

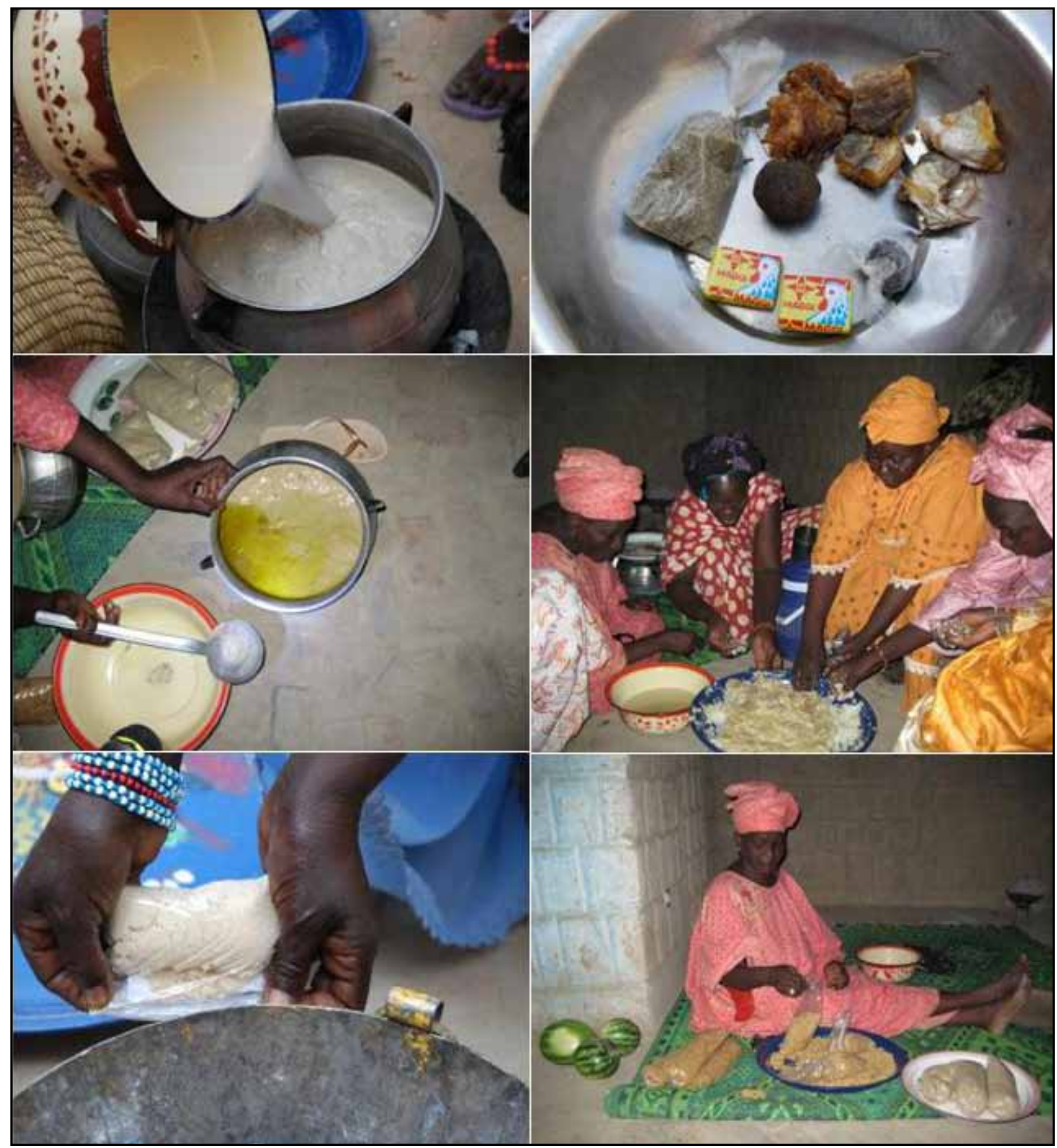

Figure 8. Seed processing into food items in the region of Tombouctou, Mali (continued). The flour of Kaneye and Musa Musa is used to make a thick sauce. The sauce can for instance be 'spiced' with dried fish, spices, and Maggi cubes. Oil is floating on the surface of the sauce. The oil can be separated from the sauce as a by-product, which can be used for cooking other dishes. Oil may also be produced directly by boiling flour and water. - The sauce is typically served with rice. The Bali Bali and flour products are sold locally after packing in plastic bags. The plastic bags are tied with a knot or closed using the edge of a hot casserole. (Photos from Bellafarandi, (c Brita Dahl Jensen). 
ties. The heat tolerance of the crop is a trait that may become even more important for future plant production in the area in the perspective of climate change.

\section{Acknowledgements}

This study was supported by a research grant from Danida (919-LIFE) and a travel grant from Mali Folkecenter, Bamako for the second trip to Tombouctou in October 2008. We thank colleagues at Institut d'Economie Rurale in Bamako, Gao, and Diré, Tombouctou region, for valuable assistance and information about watermelon cultivation. We thank the local families and producers of the pastèques for inspiring discussions and demonstrations of their production of watermelons and the locally derived products. We are grateful to the womens' group 'ALBARAKA' for demonstration of seed transformation processes. This essay is dedicated to the people of Tombouctou with the wish to generate awareness of the potential of the watermelon crop, to conserve local types and to increase food security and income.

\section{Literature cited}

Elhadj, S. 2008. An oral legend from Tombouctou. further documented in: Elhadj, S.: Tombouctou la mystérieuse: Fondation. Written text document (no year, 16 pp.). A copy is obtainable from: Institut des Hautes Etudes et de Recherches Islamiques - Ahmed Baba (IHERI-AB), BP 14, Tombouctou, Mali. www.sum.uio.no/research/mali/timbuktu/cedrab/index.html
FAOSTAT. 2010. Production. Crops. FAOSTAT. Food and Agriculture Organization of the United Nations, Rome. http://faostat.fao.org/site/567/default.aspx\#ancor.

Loukou, A.L., D. Gnakri, Y. Djè, A.V. Kippré, M. Malice, J.P. Baudoin \& I.A. Zoro. 2007. Macronutrient composition of three cucurbit species cultivated for seed consumption in Côte d'Ivoire. African Journal of Biotechnology 6:529533.

DRA. 2008. Data retried from database at: Direction Régionale de l'Agriculture de Tombouctou, Ministère de l'Agriculture, BP 65, Tombouctou, Mali. (Data obtained from D. Maïga.)

van der Vossen, H.A.M., O.A. Denton \& I.M. El Tahir. 2004. Citrullus lanatus (Thunb.) Matsum. \& Nakai. Pp. 185-191 in Plant Resources of Tropical Africa 2. Vegetables. Edited by G.J.H. Grubben \& O.A. Denton. PROTA Foundation, Wageningen, Netherlands, Backhuys Publishers, Leiden, Netherlands, CTA, Wageningen, Netherlands.

World Weather. 2010. Weather information for Tombouctou, Mali. in World Weather Information Service. World Meteorological Organization, Hong Kong. http://worldweather.wmo.int.

Zeven, A.C. 1998. Landraces: A review of definitions and classifications. Euphytica 104:127-139. 